\title{
Biomedical waste management practices in a tertiary-care hospital in Punjab
}

\author{
Meenu Kalia, Amrit Virk, BP Gupta, Jasdeep Singh \\ Correspondence to: Meenu Kalia, E-mail: meenusharma75@gmail.com
}

Received September 25, 2014. Accepted October 7, 2014

\section{Abstract}

Background: Biomedical waste (BMW) has recently emerged as an issue of major concern not only to hospitals and nursing homes, but also to the environmental and law enforcing agencies, media, and the general public. BMW forms approximately $1 \%-2 \%$ of the total municipal solid waste stream.

Objectives: The aims of the study were the following: to get background information about the disposal of hospital waste; to determine the awareness regarding waste management practices; to document the waste management practices; and to suggest the possible remedial measures, if required.

Subjects and Methods: A cross-sectional study was conducted in a medical college hospital in Patiala district. A survey of the personnel handling and monitoring the BMW was carried out using a scientifically prescribed questionnaire.

Results: More than $90 \%$ of the nurses and laboratory technicians were well aware of the proper disposal of the sharps and infected waste, but only $50 \%$ of the sweepers could satisfactorily answer about the same. Among nurses, approximately $90 \%$ were aware that improper management of BMW causes environmental pollution and injuries, whereas $60 \%$ of nurses and laboratory technicians could enlist the diseases transmitted by improper handling of BMW. Approximately 40-60\% of ward boys and sweepers were aware of the effects of poor handling of BMW on environment and the injuries caused by it, but none of them could tell the diseases transmitted by the improper recycling of hospital waste or by improper handling of BMW.

Conclusion: The human element is found to be far more important than the technology. Almost any system of treatment and disposal of BMW that is operated by well-trained and well-motivated staff can provide greater protection to staff, patients, and the community than an expensive and sophisticated system that is managed by staff who do not understand the risk and the importance of their contribution.

KEY WORDS: Biomedical waste, health care, lab technician, staff nurse

\section{Introduction}

All activities of living beings on earth produce waste in some form or other. Normally, aerobic and anaerobic processes in the environment degrade such products. The process of natural biodegradation could not keep pace with the enormous increase in the waste generated by the overincreasing population and its necessities. ${ }^{[1]}$ The last decade observed a significant increase of public concern regarding BMW disposal.

\begin{tabular}{|l|l|}
\hline Website: htp://www.jmsph.com & Access this article online \\
\hline DOI: 10.5455/ijmsph.2015.2509201434 & \\
\hline
\end{tabular}

It is ironic that the health-care centers, which restore and maintain community health, are also threatening their wellbeing. Poor waste management practices pose a huge risk to the health of the public, patients and professionals, and contribute to environmental degradation. ${ }^{[2]}$ The waste produced in course of health-care activities, which usually includes sharps, human tissues or body parts and other infectious materials, is called hospital solid waste or biomedical solid waste. ${ }^{[3,4]}$

Biomedical waste has recently emerged as an issue of major concern not only to hospitals, nursing homes, but to the environmental and law-enforcing agencies, media, and the general public also. ${ }^{[5]}$ BMW is forming approximately $1 \%-2 \%$ of the total municipal solid waste stream. ${ }^{[6]}$

The data available show that in India, approximately $2 \mathrm{~kg} /$ bed/day of such waste is generated. ${ }^{[7]}$ The concern regarding $\mathrm{BMW}$ is mainly due to the presence of a high concentration of pathogenic organisms in it. The diseases that can be transmitted are numerous but the most significant ones are hepatitis $B$, hepatitis $C$, and AIDS. ${ }^{[8]}$ 
Therefore, improper handling of solid waste in the hospital may increase the airborne pathogenic bacteria, which could adversely affect the hospital environment. The risk of human immunodeficiency virus (HIV) and hepatitis B in the community, especially among health-care providers, has led to increasing awareness about the risk associated with wrong handling of BMW. This emphasizes the need to evolve and implement strategies for safe and suitable methods of disposal of waste material generated at different sites in health-care delivery system. The proper management of health-care waste depends on good administration and organization along with adequate legislation, financing, and active participation of trained and informed staff. ${ }^{[9,10]}$

All individuals exposed to hazardous waste are potentially at risk. The main groups at risk are those belonging to medical profession, patients in the hospital, visitors to the hospital, workers in support group allied to hospitals (laundry, waste handlers, and transporters), and workers in waste disposal facilities such as landfills or incinerators including scavengers.

The Government of India (Notification 1998) ${ }^{[11]}$ specifies that hospital waste management is part of hospital hygiene and maintenance activities. The rule states that all health-care institutes will have to make arrangements to ensure that such waste is handled and managed without adverse health effects to human beings and environment. In case of non-compliance, the occupier may be liable for punishment. This involves management of the activities, which are mainly engineering functions, such as collection, transportation, operation/treatment of processing systems, and disposal of waste. However, initial segregation and storage activities are the responsibility of nursing personnel who are engaged in the hospital. ${ }^{[12]}$

According to WHO (Biomedical Waste 2004), the human element is more important than the technology alone. Any system of treatment and disposal of BMW that is operated by well-motivated staff can provide more protection for staff, patients, and the community than an expensive or sophisticated system that is managed by staff who do not understand the risks and importance of their contributions. ${ }^{[13]}$

There are about 1.6 million health-care workers at approximately 27,500 health-care facilities in India. ${ }^{[14]}$ Looking at the existing scenario and seriousness of the issue, this study was conducted to assess the procedure followed to handle and dispose the BMW in a tertiary-care hospital of Punjab.

\section{Materials and Methods}

A cross-sectional study was conducted in a medical college hospital in Patiala district. Gian Sagar Medical College and Hospital, Banur, is a 400-bedded tertiary-care hospital situated $35 \mathrm{~km}$ from Chandigarh. It caters to a daily inflow of more than 600 patients. The workforce of the hospital consists of 250 doctors, 400 nurses, and 500 other support staff that include paramedical staff house-keeping staff. A survey of the personnel handling and monitoring the BMW using a scientifically prescribed questionnaire was carried out to evaluate the know-how, outlook, and practices of employees toward waste management.

Along with this the knowledge of the participants regarding BMW handling was also assessed. The data collected included personal details, awareness about infectivity; segregation, transport and disposal of BMW, and practices regarding the same were also evaluated.

The information gathered by questionnaires was verified by personal observations.

A total of 146 persons comprising nurses, laboratory technicians, ward boys, and sweepers of various departments who could be contacted during three visits were interviewed. The participants were explained the purpose of the study in vernacular. The data collected were analyzed and expressed in percentages.

\section{Inclusion Criteria}

All the participants who consented to be a part of the study and those who were on duty were included in the study.

\section{Exclusion Criteria}

Temporary staff, trainees, and contract workers were not included in the study.

\section{Results}

Table 1 shows that majority of the nurses and laboratory technicians were graduates, whereas most of the sweepers $(79 \%)$ had studied up to primary level only. Of the respondents, $68 \%$ were men.

Here, $41 \%$ of nurses and $43 \%$ of laboratory technicians were in the age group of $25-34$ years whereas $71 \%$ of sweepers were in the age group of $<25$ years.

Table 2 shows that all respondents had good knowledge about the types of waste material generated in a hospital,

Table 1: Demographic characteristics

\begin{tabular}{lccc}
\hline Variable & $\begin{array}{c}\text { Nurses } \\
(\boldsymbol{n}=\mathbf{5 6}), \%\end{array}$ & $\begin{array}{c}\text { Lab technicians } \\
(\boldsymbol{n}=\mathbf{3 9}), \%\end{array}$ & $\begin{array}{c}\text { Sweepers } \\
(\boldsymbol{n}=\mathbf{5 1}), \boldsymbol{\%}\end{array}$ \\
\hline Education & & & - \\
$\quad$ Illiterate & - & - & 21 \\
Primary & - & - & 79 \\
Secondary & 69 & 74 & - \\
Graduation & 31 & - & - \\
Postgraduation & - & & 68 \\
Gender & & 89 & 32 \\
Male & 06 & 11 & \\
Female & 94 & & 71 \\
Age & & 32 & 22 \\
$<25$ & 23 & 43 & 07 \\
$25-34$ & 41 & 22 & - \\
$35-44$ & 22 & 03 & \\
$>45$ & 14 & & \\
\hline
\end{tabular}


although the level of knowledge was higher among nurses as compared to the ward boys and sweepers.

Most of the nurses and laboratory technicians were aware of the health hazards caused by BMW. Here, $63 \%$ of nurses and $54 \%$ of laboratory technicians were able to tell about diseases transmitted by improper recycling of wastes.

Approximately $40-60 \%$ of ward boys and sweepers were aware of the effects of poor handling of BMW on environment and the injuries caused by it, but none of them could tell the diseases transmitted by the improper recycling of hospital waste or by improper handling of BMW.

More than $90 \%$ of nurses and laboratory technicians were well aware of the proper disposal of the sharps and infected waste but only $50 \%$ of the sweepers could satisfactorily answer about the proper disposal of sharps and infected materials.

Table 3 shows that all the wards and laboratories had properly positioned dustbins and also that color coding was followed. The charts were also displayed at all important positions. Segregation of the waste was carried out at the site of generation, but the records of waste management were not maintained in any of the laboratories or wards.

Functional needle destroyers were available at all sites where sharps were used. Along with this, sufficient amount of disinfectant was also available. Disposal of sharps was carried out satisfactorily.

Table 4 shows that immunization status for tetanus and hepatitis $B$ is very low among sweepers (12\% and $7 \%)$ though it is satisfactory among nurses and laboratory technicians.

Gloves and aprons were the only protective devices used. Sweepers were not using any of the protective devices except gloves $(80 \%)$.

\section{Discussion}

Biomedical waste management requires diligence and care from a chain of people, starting from nurses and doctors who use the equipment and supplies that become waste, continuing through the cleaning workers who carry away

Table 2: Level of knowledge about type of waste material \& its disposal

\begin{tabular}{lccc}
\hline Types of waste material & $\begin{array}{c}\text { Nurses } \\
(\boldsymbol{n}=\mathbf{5 6}), \\
\%\end{array}$ & $\begin{array}{c}\text { Lab } \\
\text { technicians } \\
(\boldsymbol{n}=\mathbf{3 9}), \%\end{array}$ & $\begin{array}{c}\text { Sweepers } \\
(\boldsymbol{n}=\mathbf{5 1}), \\
\%\end{array}$ \\
\hline $\begin{array}{l}\text { Stationary, papers } \\
\text { Sharp Instruments }\end{array}$ & 94 & 91 & 41 \\
$\quad$ (i.e., needles, blades) & 91 & 91 & 59 \\
Cotton & & & 57 \\
Infected waste & 91 & 86 & 61 \\
Radioactive waste & 93 & 89 & 0 \\
Material health hazards & 13 & 06 & $\mathbf{4 8}$ \\
$\quad$ Environmental & & & $\mathbf{5 7}$ \\
Injuries & $\mathbf{7 8}$ & $\mathbf{7 3}$ & $\mathbf{0}$ \\
$\quad$ Diseases transmitted by & $\mathbf{6 5}$ & $\mathbf{9 1}$ & $\mathbf{5 4}$ \\
$\quad$ recycling & & &
\end{tabular}

Table 3: Components of segregation and collection in the hospital

\begin{tabular}{lcc}
\hline Components & $\begin{array}{c}\text { Hospital } \\
\text { wards (\%) }\end{array}$ & $\begin{array}{c}\text { Laboratories } \\
\text { (\%) }\end{array}$ \\
\hline $\begin{array}{l}\text { Biomedical waste management } \\
\quad \text { Segregation at the site of }\end{array}$ & 94 & 87 \\
$\quad$ generation & 100 & 97 \\
$\quad$ Labeled and signed & 90 & 86 \\
$\quad$ Strict implementation & 100 & 100 \\
$\quad$ Correct position of bins & 100 & 100 \\
Charts displayed & - & - \\
$\quad$ Records maintained & & \\
Sharps management & 90 & 88 \\
$\quad$ Destroyed individually & 100 & 100 \\
$\quad$ Sufficient disinfectant available & 100 & 100 \\
$\quad$ Functional needle destroyer & & \\
\hline
\end{tabular}

waste to off-site transport companies, and finishing with the technology operator responsible for ensuring that residues are disposed off in the proper way. This study was conducted to assess the waste management, that is, handling and treatment of BMW in a private college and to judge the knowledge of employees regarding the same.

Table 2 shows that all respondents had good knowledge about types of waste material generated in hospital although level of knowledge was more among nurses as compared to the ward boys and sweepers. More than $90 \%$ of nurses and laboratory technicians were well aware of the proper disposal of the sharps and infected waste, but only $50 \%$ of the sweepers could satisfactorily answer about the proper disposal of sharps and infected material. The results are comparative with the findings of Saraf et al. ${ }^{[14]}$ The high level of knowledge among nurses and laboratory technicians may be attributed to the fact that all the nurses and laboratory technicians receive training on BMW management after

Table 4: Occupational safety and training

\begin{tabular}{lccc}
\hline Variables & $\begin{array}{c}\text { Nurses } \\
(\boldsymbol{n}=\mathbf{5 6}), \\
\%\end{array}$ & $\begin{array}{c}\text { Lab } \\
\text { technicians } \\
(\boldsymbol{n}=\mathbf{3 9}), \%\end{array}$ & $\begin{array}{c}\text { Sweepers } \\
(\boldsymbol{n}=\mathbf{5 1}), \%\end{array}$ \\
\hline $\begin{array}{l}\text { Tetanus toxoid } \\
\quad \text { immunization }\end{array}$ & 72 & 67 & 12 \\
$\begin{array}{l}\text { Hepatitis B immunization } \\
\text { Injuries from sharps }\end{array}$ & 85 & 88 & 07 \\
$\quad \begin{array}{l}\text { Exposure to infectious } \\
\text { material }\end{array}$ & 13 & 07 & 10 \\
Personal protective devices used & 10 & 20 \\
$\quad$ Gloves & 98 & 94 & \\
$\quad$ Boots & - & - & - \\
$\quad$ Aprons & 100 & 100 & - \\
$\quad$ Masks & 96 & 28 & \\
$\quad$ Caps & 20 & - & - \\
$\quad$ Training received & 75 & 77 & 32 \\
\hline
\end{tabular}


joining the institute. Nursing superintendent is responsible for holding such trainings for the new employees with the help of relevant faculty from nursing college and medical college. The senior nursing staff and sisters in charge of the ward are given the responsibility for implementation of the BMW management rules by the authorities. The sweepers and ward boys are not given any formal training. The little training that they receive is from their in charge who is also not a qualified person for the purpose. Soliman and Ahmed ${ }^{[15]}$ and Boss et al. ${ }^{[16]}$ also observed the lack of training of the staff in their respective studies. Knowledge about the disposal of radioactive wastes was found to be very limited among all types of respondents. This may be due to the fact that not much radioactive waste materials is generated in this hospital as there is no radiotherapy unit and thus less stress is given on this aspect during training.

Among nurses, approximately $90 \%$ were aware that improper management of waste causes environmental pollution and injuries, whereas $60 \%$ of nurses and laboratory technicians could enlist the diseases transmitted by improper handling of BMW.

Approximately, $40 \%-60 \%$ of ward boys and sweepers were aware of the effects of poor handling of BMW on environment and the injuries caused by it but none could tell the diseases transmitted by the improper recycling of hospital waste or by improper handling of BMW. The workers who are actually at risk of contracting diseases from BMW are lacking greatly in knowledge regarding its handling.

Continuous monitoring and evaluation are necessary to ensure that policies and procedures are followed. Even a small proportion of badly managed waste can be potentially dangerous. The $\mathrm{WHO}$ acknowledges this as a problem and observes that the human element is as important as technology in waste management.

Table 3 depicts the observational findings of the segregation and collection of the BMW at the site of generation. Segregation is the key to the management of BMW. Poor segregation not only puts the staff and public at risk but also increases handling and disposal cost of hospital waste. It was found that $100 \%$ hospital wards and almost laboratories were strictly complying with the rules of waste segregation. BMW was segregated at the site of generation, all wastebins were labeled properly as found by Pandit et al. ${ }^{[17]}$ and Abor and Bouwer. ${ }^{[18]}$ Color-coding charts were found displayed contrary to findings of Verma et al. ${ }^{[19]}$ No records regarding BMW were kept.

Management of sharps was satisfactory with sufficient disinfectant available. Similar findings were reported in a study conducted in Shimla. ${ }^{[20]}$

Immunization status for tetanus and hepatitis B was found to be very low among sweepers $(12 \%$ and $7 \%)$ though it was good among nurses and laboratory technicians. It was due to the institute's policy of immunizing the staff at the time of joining. This is in corroboration with the findings of De Silva and Hoppe. ${ }^{[21]}$

Workers handling BMW were not equipped with protective devices. Gloves were the most commonly used protective device. Apron was used by all nurses and laboratory technicians.

Continuous evaluation and monitoring are necessary to ensure that policies and procedures related to BMW handling are followed. Even a small proportion of badly managed waste can be potentially dangerous. WHO acknowledges this as a problem and observes that the human element is as important as technology in waste management.

\section{Conclusion}

The human element is far more important than the technology. Almost any system of treatment and disposal of BMW that is operated by well-trained and well-motivated staff can provide more protection for staff, patients, and the community than an expensive and sophisticated system that is managed by staff who do not understand the risks and the importance of their contributions.

\section{References}

1. De Roos RL. Environmental concerns in hospital waste disposal. Hospitals 1974;48:120-2.

2. Acharya DB, Singh M. The Book of Hospital Waste Management, 1st edn. New Delhi: Minerva Press, 2000.

3. Baveja G, Muralidhar S, Aggarwal P. Hospital waste management—an overview. Hosp Today 2000;39:557-66.

4. Al-Mutair N, Terro M, Al-Khaleefi AL. Effects of recycling hospital ash on the compression properties of concrete: statistical assessment and predicating model. Build Environ 2004;39: 557-66.

5. Hospital waste finds its ways back to the streets, say study. Hindustan Times, Oct 22, 1999.

6. Kishore J, Goyal P, Sagar B, Joshi TK. Awareness about bio medical waste management and infection control among dentist of a teaching hospital in New Delhi, India. Ind J Dent Res 2000; 11(4):157-61.

7. Grover PD. Management of hospital waste-an overview. Proc Natl Workshop Manag Hosp Waste 1998:16-18.

8. Wallace LP, Zaltzman R, Burchinal IC. Where solid waste comes from; where it goes. Modern Hosp 1972;121(3):92-5.

9. Hashmi SK, Shahab S. Hospital and biomedical waste management. In: Community Medicine and Public Health. Iliyas M (Ed), 4th edn. Karachi: Time Publishers, 2003, 426-37.

10. Horvath A. Management of waste disposal in medical institutions. Rv Hetil 1991;132:919-24.

11. Info Nugget. Hospital Waste Management and Biodegradable Waste. Govt. of India, Press Information Bureau. Available at: http://www.pib.nic.in/infonug/infonug.99/i3008991.html (last accessed on May 28, 2014).

12. Patil GV, Pokhrel K. Biomedical solid waste management in an Indian hospital: a case study. Waste Manag 2005;25:592-9.

13. Shah S, Mehta M, Mukherjee MD. Occupational Health Hazards Encountered at Health Care Facility and Medical College in India. American Industrial Hygiene Association. Available at: http://www.aiha.rrg/abs01/01 hea.html (last accessed on June 26, 2009). 
14. Saraf $Y$, Shinde M, Tiwari SC. Study of awareness status about hospital waste management among personnel and quantification. Indian J Community Med 2006;31(2):111 .

15. Soliman SM, Ahmed AL. Overview of biomedical waste management in selected governorates in Egypt: a pilot study. Waste Manag 2007;27:1920-3.

16. Boss UJ, Moli GP, Roy G. Biomedical waste generation in Pondicherry Govt. Hospital and its management implications. J Environ Health 2009;71:54-8.

17. Pandit NB, Mehta HK, Kartha GP. Management of biomedical waste: awareness and practices in a district of Gujarat. Ind J Pub Health 2005;49:245-7.

18. Abor PA, Bouwer A. Medical waste practices in a southern African hospital. Int J Health Care Qual Assur 2008;21:356-64.
19. Verma LK, Mani S, Sinha N. Biomedical waste management in nursing homes and smaller hospitals in Delhi. Waste Manag 2008;28:2723-34.

20. Kumar S. Biomedical Waste Management Practices in Shimla City, 2011: A thesis.

21. De Silva CE, Hoppe AE. Hospital waste management in the South of Brazil. Waste Manag 2005;25:600-5.

How to cite this article: Kalia M, Virk A, Gupta BP, Singh J. Biomedical waste management practices in a tertiary-care hospital in Punjab. Int J Med Sci Public Health 2015;4:179-183

Source of Support: Nil, Conflict of Interest: None declared. 